\title{
Effects on Ultrastructure, Composition and Specific Surface Area of the Gills of Odontesthes bonariensis Under Subchronic Glyphosate- Based Herbicide Exposure
}

\author{
Renata J. Menéndez-Helman ${ }^{1,4} \cdot$ Leandro A. Miranda $^{2} \cdot$ Alfredo Salibián $^{3} \cdot$ María dos Santos Afonso $^{1}$ (D)
}

Received: 25 May 2020 / Accepted: 19 October 2020 / Published online: 7 November 2020

(c) Springer Science+Business Media, LLC, part of Springer Nature 2020

\begin{abstract}
Gills represent one of the major sites of gas exchange of fish, consequently they are in continuous close contact with the aquatic environment and its pollutants. In the present study the effects on gills of pejerrey fish, Odontesthes bonariensis, under glyphosate-based herbicide subchronic exposure were analyzed. Adult animals were exposed to sublethal concentrations of a glyphosate-based commercial formulation (1 and $10 \mathrm{PMG} \mathrm{mg} \mathrm{L}{ }^{-1}$, PMG: glyphosate active ingredient) for 15 days, while control group was maintained in rearing water. Ultrastructural changes in gills were observed by scanning electron microscopy (SEM). The composition of the surface epithelium and specific surface area were determined by energy dispersive spectroscopy (EDS) and $\mathrm{N}_{2}$ (g) adsorption-desorption isotherms, respectively. The herbicide exposure induced severe alterations in gill ultrastructure, as shown in the SEM micrographs. Accordingly, an increase in surface area of the gills of exposed animals was determined. These results support that gills parameters of freshwater fish are sensitive morphological biomarkers for glyphosate exposure.
\end{abstract}

Keywords Glyphosate-based herbicide · Gill ultrastructure · SEM · Specific surface area $\cdot$ Pejerrey fish Odontesthes bonariensis

María dos Santos Afonso

dosantos@qi.fcen.uba.ar

Renata J. Menéndez-Helman

rmenendez@qb.fcen.uba.ar

Leandro A. Miranda

lmiranda@intech.gov.ar

Alfredo Salibián

prodea@mail.unlu.edu.ar

1 INQUIMAE, Facultad de Ciencias Exactas y Naturales, CONICET - Universidad de Buenos Aires, Pabellón II, Ciudad Universitaria, C1428EHA Buenos Aires, Argentina

2 Laboratorio de Ictiofisiología y Acuicultura, Instituto Tecnológico de Chascomús (INTECH), CONICET UNSAM, B7130IWA Chascomús, Argentina

3 Programa de Ecofisiología Aplicada (PRODEA), Instituto de Ecología y Desarrollo Sustentable (INEDES-CONICET), Universidad Nacional de Luján, B6700ZBA Luján, Argentina

4 Present Address: IQUIBICEN, Facultad de Ciencias Exactas y Naturales, CONICET - Universidad de Buenos Aires, Pabellón II, Ciudad Universitaria, C1428EHA Buenos Aires, Argentina
Water pollution by agrochemicals is one of the most serious problems for the conservation of aquatic ecosystems. In Argentina, transgenic soybean cultivation has continued growing over the last decade. The cropped area increased from approximately 9 million ha at the end of the 1990 decade up to 18 million ha in 2016/17 (MAGyP 2018). Consequently, the pesticide application rates (herbicides plus insecticides, fungicides, acaricides, among others) increased from 38,000 tons of active ingredients in 1995 (before the introduction of a GM glyphosate-tolerant crops) to more than 190,000 tons in 2017 (Food and Agriculture Organization, FAO 2018). Glyphosate [ $N$-(phosphonomethyl) glycine; $\mathrm{PMG}]$ is the main broad-spectrum herbicide used for the control of a wide range of weeds in soybean crops. The application of glyphosate formulations commonly used in Argentine agriculture increased from 70,000 tons to more than 180,000 tons between 1999 and 2014 (CASAFE 2015). Once applied to the crop, part of the herbicide may remain adsorbed to soil particles until the degradation by microorganisms. Also, the herbicide can be mobilized by the influence of several factors such as wind, rain or irrigation that increase infiltration and surface run-off (Pérez et al. 2011; 
World Health Organization, WHO 1994). Thus, the organic compound can reach nearby aquatic environments and biota can be adversely affected. In this regard, some authors have reported high levels of PMG and its metabolite aminomethylphosphonic acid (AMPA) in sediment, soil and water, particularly in the surroundings of cultivation areas (Peruzzo et al. 2008; Ronco 2011). Moreover, other authors reported lower PMG levels but a high frequency of detection (Primost et al. 2017; Mac Loughlin et al. 2020), suggesting that PMG could be considered as "pseudo-persistent" pollutant because it is continuously introduced to the environment under real-world agricultural management practices.

PMG does not exhibit a significant acute lethal toxicity to freshwater fish (LC50-96 h $>100 \mathrm{mg} \mathrm{L}^{-1}$ ) (Carriquiriborde 2010; Folmar et al. 1979; Menéndez-Helman et al. 2013; Nešković et al. 1996). However, several authors have noted that formulations containing the herbicide active ingredient together with co-adjuvants (glyphosate-based herbicides, GBH) exhibit a significant increase in toxicity to diverse aquatic organisms (algae, bacteria, protozoans, invertebrates and fish) (Menéndez-Helman et al. 2013; Pérez et al. 2011). Moreover, several sublethal effects of the PMG and GBH have also been reported in fish including histopathological disorders, metabolic changes associated with oxidative stress, energy disturbances, neurotoxicity, genotoxicity, among others (Menéndez-Helman et al. 2012, 2013, 2015, and references cited therein).

The pejerrey (Odontesthes bonariensis; Cuvier and Valenciennes, 1835) belongs to the Atherinopsidae family and is considered native to shallow lakes of Buenos Aires Province, Argentina, and probably in southern Brazil (Dyer 2006). This teleost presents socioeconomic relevance for commercial and sport fishing (Berasain et al. 2015), and additionally it is a promising species for aquaculture (Somoza et al. 2008). In several lethal toxicity studies using pejerrey as test organism, relatively low LC50-96 h values for different heavy metals and organic compounds have been estimated (Carriquiriborde and Ronco 2006; Carriquiriborde 2010). This fact confirms the sensitivity of $O$. bonariensis to environmental pollutants.

The fish gill is a very complex and multifunctional organ, involved in vital functions, such as gas exchange, ion exchange, acid-base balance, and nitrogenous waste excretion. This organ is in contact with the surrounding water, and its large surface area makes it an important target for waterborne pollutants (Cavalcante et al. 2008; Ferrari et al. 2009; Jiraungkoorskul et al. 2003). Thus, the ultrastructural responses are sensitive enough to indicate early effects on the organism exposed to low concentrations of chemicals, and they become potentially useful tools as morphological biomarkers to assess environmental pollution.

In this context, the aim of this study was to evaluate the exposure of pejerrey to a glyphosate-based herbicide, specifically the effects on the ultrastructure, the composition of the surface epithelium and specific surface area of gills.

\section{Materials and Methods}

The bioassay was conducted at the aquaculture facilities of the Instituto Tecnológico de Chascomús (INTECH, Chascomús, Argentina) during the spring season. Three tanks, containing $120 \mathrm{~L}$ of groundwater (salinity $15 \mathrm{~g} \mathrm{~L}^{-1}$ ), continuously aerated, were located outdoors. Adult fish (2 years old) were selected from the stock reared at the INTECH and four males and two females were placed in each tank (to prevent the disruption of the normal reproductive cycle). After acclimatization for $48 \mathrm{~h}$, fish were transferred to another container while the commercial formulation of glyphosate was added to the tanks, after which fish were placed back into the tanks. Glifosato II ${ }^{\circledR}$ (manufactured by Atanor, Argentina) was the tested GBH formulation that contained $43.8 \% \mathrm{w} / \mathrm{v}$ mono potassium salt of PMG simulating a single contamination event. The doses used were 0 (control), 1 or $10 \mathrm{mg}^{\mathrm{PMG}} \mathrm{GBH}_{\mathrm{GH}} \mathrm{L}^{-1}$ (PMG $_{\mathrm{GBH}}$ : $\mathrm{PMG}$ expressed as glyphosate acid contained in GBH solutions). During the assays, fish were fed commercial fish food pellets (Shulet, Buenos Aires, Argentina). The static trials were carried out for 15 days. Temperature and dissolved oxygen (DO) were measured in each tank every 2 days at 2 p.m. (the mean values \pm standard error were $19 \pm 1^{\circ} \mathrm{C}$ and $6.2 \pm 0.3 \mathrm{mgL}^{-1}$, respectively) and samples of the assay media were taken at the initial and final time to quantify the analytical concentration of the herbicide. At the end of the exposure period, fish were anesthetized with benzocaine $\left(100 \mathrm{mg} \mathrm{L}^{-1}\right)$, weighed (W), and the total length $\left(\mathrm{L}_{\mathrm{T}}\right)$ was measured. These parameters were used to calculate the Fulton's condition factor index $\left(\mathrm{K}=\left[(\mathrm{W} \times 100) \times\left(\mathrm{L}_{\mathrm{T}}\right)^{-3}\right]\right)$. After this, the dissections were performed and gills were removed intact. Gills were washed with phosphate buffer $(0.1 \mathrm{M}, \mathrm{pH} 7.2)$, fixed for $3 \mathrm{~h}$ in $2.5 \%$ glutaraldehyde solution in phosphate buffer and 4 additional washes with phosphate buffer were carried out during the next $48 \mathrm{~h}$. Later, dehydration was carried out rinsing during $30 \mathrm{~min}$ with a graded series of $10 \%, 30 \%$ and $50 \%$ ethanol. Finally, samples were stored in $70 \%$ ethanol until analysis.

Gills were transferred from $70 \%$ ethanol to absolute ethanol, and samples were dried by Critical Point technique (Anderson 1951). The method is based on the displacement of ethanol by liquid $\mathrm{CO}_{2}$ under high pressure up to critical pressure, and then heating until a temperature higher than critical temperature. This process allows $\mathrm{CO}_{2}$ to pass from liquid to gaseous phase, at pressure and temperature conditions above the critical point of $\mathrm{CO}_{2}$, without forming a liquid/gas interface. Therefore, tissue samples were dried without collapsing or deforming their original structure. Then samples were fixed 
on stubs by carbon conductive tape and coated with gold/palladium using a sputter coater (Thermo VG Scientific Sc7620). The surface morphology of the samples, an advanced form of high spatial resolution imaging, was visualized by a scanning electron microscope (SEM; Philips XL30 TMP New Look) in high vacuum conditions.

The elemental composition of the surface after metal binding was determined by energy dispersive spectroscopy (EDS, Oxford Instruments detector with INCA software) coupled to scanning electron microscope with field emission gun (FEGSEM Zeiss Supra 40). In this case samples were coated with gold. One holobranch of each specimen $(n=2$ specimens per treatment) was bombarded by the SEM's electron beam in three different surface places for EDS analysis.

Specific surface area (SSA) is a property defined as the total surface area of a material per mass unit expressed in $\mathrm{m}^{2} \mathrm{~g}^{-1}$. SSA was determined using a Micrometrics AccuSorb 2100 by $\mathrm{N}_{2}(\mathrm{~g})$ adsorption-desorption isotherms recorded at $77 \mathrm{~K}$ of temperature. Gill samples were degassed for $12 \mathrm{~h}$ at $150^{\circ} \mathrm{C}$ prior to measurement. The SSA was calculated using Langmuir model. Also, the pore volume (micropore and mesopore volume) define as the total volume of very small openings in a bed of adsorbent particles was calculated using the Gurvich rule from the plateau-like region of the nitrogen adsorption isotherm at a relative pressure of $\mathrm{p} / \mathrm{p}^{0}=0.99$, which is in the plateau-region of the isotherm (Lowell et al. 2004). For SSA analysis, holobranch from 5 to 6 specimens of each treatment were analyzed.

PMG concentrations in the exposure media $\left(\mathrm{PMG}_{\mathrm{GBH}}\right)$ were analyzed by ion chromatography (Zhu et al. 1999), using a Dionex DX-100 chromatograph with a conductivity detector and a $25 \mu \mathrm{L}$ sample loop. Dionex AG-4 and AS-4 were used as analytical columns. A mixture of $\mathrm{NaOH} / \mathrm{CO}_{3}{ }^{2-}(4 \mathrm{mM} / 9 \mathrm{mM})$ was used as eluent with a flow rate of $1 \mathrm{~mL} \mathrm{~min}^{-1}$. Samples from three tanks and standards $(0,0.5,1,5,10,25 \mathrm{mg}$ $\mathrm{PMGL}^{-1}$ ) freshly prepared were injected. PMG standard was purchased from Sigma (St. Louis, MO, USA). The detection limit of the method was $0.1 \mathrm{mg} \mathrm{L}^{-1}$. Data acquisition was performed using the Clarity Lite software.

The statistical comparisons for morphometric $\left(\mathrm{L}_{\mathrm{T}}\right.$, $\mathrm{W}$ and $\mathrm{K}$ ), SSA and elemental composition parameters between exposed groups and the control were performed using Kruskal-Wallis non-parametric ANOVA followed by Dunn's Multiple Comparison Test (GraphPad Prism Software). The level of significance for all statistical tests was set at $\alpha=0.05$.

\section{Results and Discussion}

The analytical concentrations of $\mathrm{PMG}_{\mathrm{GBH}}$ (mean \pm standard error) at the initial time were: not detectable for control group, $0.9 \pm 0.1$ and $9.2 \pm 0.4 \mathrm{mg} \mathrm{PMG}_{\mathrm{GBH}} \mathrm{L}^{-1}$ for the groups exposed to nominal concentrations of 1 and $10 \mathrm{mg} \mathrm{PMG}_{\mathrm{GBH}} \mathrm{L}^{-1}$, respectively. A significant reduction in $\mathrm{PMG}_{\mathrm{GBH}}$ occurred at the end of the exposure time, being $\mathrm{PMG}_{\mathrm{GBH}}$ no detectable $\left(<0.1 \mathrm{mg} \mathrm{L}^{-1}\right)$ in the control and the lower concentration tanks; and $1.1 \pm 0.2 \mathrm{mg}$ $\mathrm{PMG}_{\mathrm{GBH}} \mathrm{L}^{-1}$ in the higher concentration tank. Moreover, condition factor $(\mathrm{K})$ values at the final time were: $0.78 \pm$ 0.05 for the control group; $0.83 \pm 0.05$ and $0.83 \pm 0.04$ for 1 and $10 \mathrm{mg} \mathrm{PMG}_{\mathrm{GBH}} \mathrm{L}^{-1}$, respectively. No statistically significant changes in fish morphometric parameters $\left(\mathrm{L}_{\mathrm{T}}\right.$, $\mathrm{W}$ and $\mathrm{K}$ ) were found among treatments.

Scanning electron micrographs of $O$. bonariensis gills at the end of the exposure period, are shown in Fig. 1.

Gill structure of control fish included filaments and lamellae showing normal morphological features (Fig. 1a). These characteristics are in accordance to those previously reported by other authors for this species (Tano de la Hoz et al. 2014; Vigliano et al. 2006). On the other hand, fish exposed to 1 and $10 \mathrm{mg} \mathrm{PMG}_{\mathrm{GBH}} \mathrm{L}^{-1}$ exhibited gill impairment. Gill of fish exposed to $1 \mathrm{mg} \mathrm{PMG}_{\mathrm{GBH}} \mathrm{L}^{-1}$ (Fig. 1b) showed signs of disorganization, while these alterations in fish exposed to $10 \mathrm{mg} \mathrm{PMG}_{\mathrm{GBH}} \mathrm{L}^{-1}$ (Fig. 1c) were severe, in both the lamellae as well as in the interlamellar epithelium spaces. The gill damages induced by GBH include mucous globules, both in epithelium of the filaments as well as in the mucosal cells of the interlamellar space and primary lamellae. The mucus production may be interpreted as a nonspecific stress response as well as the evidence of a protective role. These effects have been previously reported by several authors in gills of fish exposed to other environmental pollutants (Ferrari et al. 2009).

The fish gill is a multipurpose organ that plays a central role in the responses to environmental changes. In this sense, gill ultrastructural biomarkers can be useful tools to characterize the health status of fish in polluted environment. Several studies have shown the adverse histopathological impacts of commercial formulations of glyphosate after acute or chronic exposure (Hued et al. 2012; Jiraungkoorskul et al. 2003; Nešković et al. 1996). Filament cell proliferation, lamellar cell hyperplasia, lamellar fusion, epithelial lifting, and aneurysm were also observed in the gills. Cavalcante et al. (2008) determined genotoxic effects by the comet assay in gill cells of Prochilodus lineatus after sublethal acute exposure to $10 \mathrm{mg} \mathrm{L}^{-1}$ of Roundup.

Other authors have also described changes in gill ultrastructure in fish exposed to glyphosate formulations (Samanta et al. 2016; 2018a, b; Senapati et al. 2009).

In order to perform a quantitative analysis of glyphosate exposure impact, the gills SSA was measured (Fig. 2). In the exposed groups an SSA increase was observed that was statistically significant for the group exposed to $1 \mathrm{mg}$ $\mathrm{PMG}_{\mathrm{GBH}} \mathrm{L}^{-1}$. 

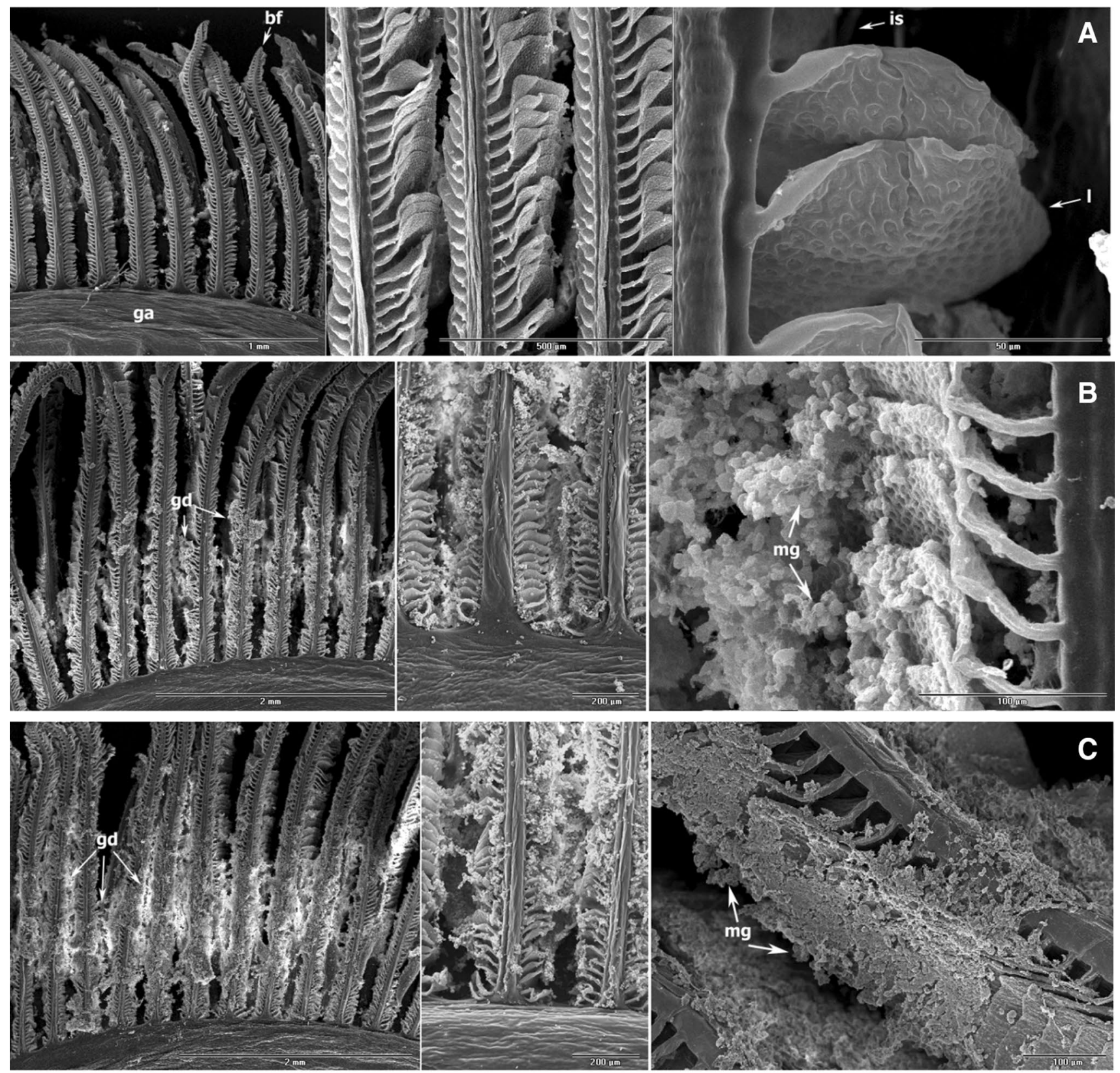

Fig. 1 Scanning electron micrographs of a holobranch of the freshwater fish Odontesthes bonariensis showing gill arch (ga), branchial filament (bf), the lamellae (l) and interlamellar spaces (is). Signs of gill disorganization (gd) including a large number of mucous glob-

The pore volume was $0.38 \pm 0.01 \mathrm{~cm}^{3} \mathrm{~g}^{-1}$ for the control group. An increasing trend was observed when the treatment concentration increased, around $10 \%$ and $18 \%$ for the groups exposed to 1 and $10 \mathrm{mg} \mathrm{PMG}_{\mathrm{GBH}} \mathrm{L}^{-1}$, respectively. This increase is indicative of the ultrastructure damage.

In addition, the results were grouped by sex and significant differences due to this factor were ruled out.

Finally, the elemental composition of gills was determined as shown in Table 1. No difference was observed in ules (mg), are observed in the exposed groups. Representative micrographs at different magnification are shown in each panel. a Gills of control group specimens. b Gills of specimens exposed to $1 \mathrm{mg}$ $\mathrm{PMG}_{\mathrm{GBH}} \mathrm{L}^{-1}$. $\mathbf{c}$ Gills of specimens exposed to $10 \mathrm{mg} \mathrm{PMG}_{\mathrm{GBH}} \mathrm{L}^{-1}$

the percentage composition of any of the elements in the exposed groups with respect to the control group. These results indicate that GBH effects involve a tissue disintegrative process without elemental composition changes. The adverse effects could be due to the active ingredient, coadjuvants and/or its metabolites.

The present results are complementary to those provided by studies performed in other species. The lowest concentration tested is environmentally relevant, as there 


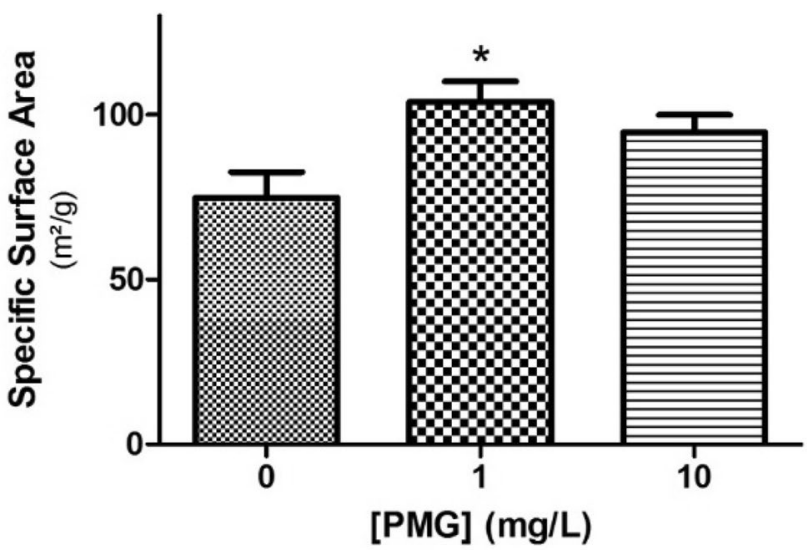

Fig. 2 Gill specific surface area of the freshwater teleost Odontesthes bonariensis (control group or exposed to 1 and $10 \mathrm{mg} \mathrm{PMG}_{\mathrm{GBH}} \mathrm{L}^{-1}$ ) determined by $\mathrm{N}_{2}$ (g) adsorption-desorption isotherms. Data as means \pm standard errors $(n=5-6)$. Asterisks indicate significant differences from control $(* p<0.05)$

Table 1 Gill elemental composition (\%) of the freshwater teleost Odontesthes bonariensis determined by EDS for control group or exposed to 1 and $10 \mathrm{mg} \mathrm{PMG}_{\mathrm{GBH}} \mathrm{L}^{-1}$

\begin{tabular}{lccc}
\hline Element & 0 & 1 & 10 \\
\hline $\mathrm{C}$ & $59 \pm 1$ & $60 \pm 1$ & $61 \pm 2$ \\
$\mathrm{~N}$ & $17.7 \pm 0.2$ & $16.3 \pm 0.03$ & $15.1 \pm 2.3$ \\
$\mathrm{O}$ & $22.5 \pm 1.3$ & $23.0 \pm 1.4$ & $23.1 \pm 0.1$ \\
$\mathrm{P}$ & $0.46 \pm 0.04$ & $0.42 \pm 0.12$ & $0.49 \pm 0.07$ \\
$\mathrm{~S}$ & $0.49 \pm 0.01$ & $0.47 \pm 0.12$ & $0.54 \pm 0.17$ \\
$\mathrm{Ca}$ & $0.07 \pm 0.05$ & $0.08 \pm 0.02$ & $0.12 \pm 0.03$ \\
\hline
\end{tabular}

Data as means \pm standard errors

have been reports of background concentrations of PMG close to $1 \mathrm{mg} \mathrm{L}^{-1}$ in water bodies of agricultural areas of the Pampas region (Peruzzo et al. 2008). In the present work, that concentration lead to changes in gill ultrastructure of pejerrey fish. These effects were supported by SEM and SSA analyses.

For future research, it would be interesting to investigate the impact of lower PMG concentrations and longer exposures on gill ultrastructure taking into account that PMG is considered a pseudo-persistent pesticide.

Acknowledgements This work was partially supported by Grants from Universidad de Buenos Aires (UBACyT 20020100100750) and Agencia Nacional de Promoción Científica y Tecnológica, Argentina (PICT 2017-2506). The authors appreciate the contribution of Lic. Fabián Tricárico, Museo Argentino de Ciencias Naturales "Bernardino Rivadavia”, in the initial phases of the study.

\section{References}

Anderson TF (1951) Techniques for the preservation of three-dimensional structure in preparing specimens for the electron microscope. Trans NY Acad Sci 13(4(Series II)):130-134

Berasain GE, Colautti DC, Remes-Lenicov M, Argemi F, Bohn VV, Miranda LA (2015) Impact of water salinity on pejerrey (Odontesthes bonariensis) fisheries in Chasicó Lake. Hydrobiologia 752:167-174

Carriquiriborde P (2010) Toxicidad de glifosato en peces autóctonos: Estudios de laboratorio y campo. In: Camino M, Aparicio V (eds) Aspectos ambientales del uso del glifosato. Ediciones INTA, pp 53-64

Carriquiriborde P, Ronco A (2006) Ecotoxicological studies on the pejerrey (Odontesthes bonariensis, Pisces Atherinopsidae). Biocell 30:97-109

CASAFE (2015) Cámara de Sanidad Agropecuaria y Fertilizantes. https://www.casafe.org/pdf/2018/ESTADISTICAS/InformeMercado-Fitosanitarios-2014.pdf

Cavalcante DGSM, Martinez CBR, Sofia SH (2008) Genotoxic effects of Roundup ${ }^{\circledR}$ on the fish Prochilodus lineatus. Mutat Res Genet Toxicol Environ Mutagen 655(1-2):41-46

Dyer HBS (2006) Systematic revision of the South American silversides (Teleostei, Atheriniformes). Biocell 30:69-88

Ferrari L, Eissa BL, Ossana NO, Salibián A (2009) Effects of sublethal waterborne cadmium on gills in three teleosteans species: scanning electron microscope study. Int J Environ Health 3(4):410-426

Folmar LC, Sanders HO, Julin AM (1979) Toxicity of the herbicide glyphosate and several of its formulations to fish and aquatic invertebrates. Arch Environ Contam Toxicol 8:269-278

Food and Agriculture Organization, FAO (2018). http://www.fao.org/ faostat/en/\#data/RP

Hued AC, Oberhofer S, Bistoni MA (2012) Exposure to a commercial glyphosate formulation (Roundup ${ }^{\circledR}$ ) alters normal gill and liver histology and affects male sexual activity of Jenynsia multidentata (Anablepidae, Cyprinodontiformes). Arch Environ Contam Toxicol 62(1):107-117

Jiraungkoorskul W, Upatham ES, Kruatrachue M, Sahaphong S, Vichasri-Grams S, Pokethitiyook P (2003) Biochemical and histopathological effects of glyphosate herbicide on Nile tilapia (Oreochromis niloticus). Environ Toxicol 18:260-267

Lowell S, Shields J, Thomas MA, Thommes M (2004) Characterization of porous solids and powders: surface area, pore size and density. Springer, Dordrecht

Mac Loughlin TM, Peluso ML, Aparicio VC, Marino DJ (2020) Contribution of soluble and particulate-matter fractions to the total glyphosate and AMPA load in water bodies associated with horticulture. Sci Total Environ 703:134717

MAGyP M, de Agricultura, Ganadería y Pesca (2018). Agricultura - Estimaciones agrícolas. https://datos.magyp.gob.ar/datas et? $\mathrm{q}=$ superficie + sembrada

Menéndez-Helman RJ, Ferreyroa GV, dos Santos Afonso M, Salibián A (2012) Glyphosate as an acetylcholinesterase inhibitor in Cnesterodon decemmaculatus. Bull Environ Contam Toxicol 88:6-9

Menéndez-Helman RJ, Miranda LA, dos Santos Afonso M, Salibián A (2015) Subcellular energy balance of Odontesthes bonariensis exposed to a glyphosate-based herbicide. Ecotoxicol Environ Saf 114:157-163

Menéndez-Helman RJ, Salibián A, dos Santos Afonso M (2013) Lethal and sublethal glyphosate effects on non-target fish species. Biomarkers responses in Cnesterodon decemmaculatus. In: Kobayashi D, Watanabe E (eds) Handbook on herbicides: biological activity, classification and health and environmental implications. Nova Publishers, Inc., New York, pp 85-110 
Nešković NK, Poleksić V, Elezović I, Karan V, Budimir M (1996) Biochemical and histopathological effects of glyphosate on carp, Cyprinus carpio. Bull Environ Contam Toxicol 56:295-302

Pérez GL, Vera MS, Miranda LA (2011) Effects of herbicide glyphosate and glyphosate-based formulations on aquatic ecosystems. In: Andreas K (ed) Herbicides and environment. InTech, Chascomus, pp 343-368

Peruzzo PJ, Porta AA, Ronco AE (2008) Levels of glyphosate in surface waters, sediments and soils associated with direct sowing soybean cultivation in North Pampasic region of Argentina. Environ Pollut 156:61-66

Primost JE, Marino DJ, Aparicio VC, Costa JL, Carriquiriborde P (2017) Glyphosate and AMPA, "pseudo-persistent" pollutants under real-world agricultural management practices in the Mesopotamic Pampas agroecosystem, Argentina. Environ Pollut 229:771-779

Ronco AE (2011) Impacto de Plaguicidas en ambientes acuáticos pampeanos: Integración de estudios químico ecotoxicológicos en experimentos de campo y laboratorio, con especial énfasis en el glifosato. In: Camino M, Aparicio V (eds) Aspectos ambientales del uso del glifosato. Ediciones INTA, pp 85-94

Samanta P, Mukherjee AK, Pal S, Kole D, Ghosh AR (2016) Toxic effects of glyphosate-based herbicide, Excel Mera 71 on gill, liver, and kidney of Heteropneustes fossilis under laboratory and field conditions. J Microsc Ultrastruct 4(3):147-155

Samanta P, Kumari P, Pal S, Mukherjee AK, Ghosh AR (2018a) Histopathological and ultrastructural alterations in some organs of Oreochromis niloticus exposed to glyphosate-based herbicide, Excel Mera 71. J Microsc Ultrastruct 6(1):35-43

Samanta P, Pal S, Senapati T, Mukherjee AK, Ghosh AR (2018b) Assessment of adverse outcome of Excel Mera 71 in Anabas testudineus by histological and ultrastructural alterations. Aquat Toxicol 205:19-24

Senapati T, Mukerjee AK, Ghosh AR (2009) Observations on the effect of glyphosate based herbicide on ultra structure (SEM) and enzymatic activity in different regions of alimentary canal and gill of Channa punctatus (Bloch). J Crop Weed 5(1):236-245

Somoza GM, Miranda LA, Berasain GE, Colautti D, Remes Lenicov M, Strüssmann CA (2008) Historical aspects, current status and prospects of pejerrey aquaculture in South America. Aquac Res 39:784-793

Tano de la Hoz MF, Longo MV, Escalante AH, Díaz AO (2014) Surface ultrastructure of the gills of Odontesthes bonariensis (Valenciennes, 1835) (Teleostei: Atheriniformes) from a temperate shallow lake. Int J Morphol 32(4):1341-1346

Vigliano FA, Aleman N, Quiroga MI, Nieto JM (2006) Ultrastructural characterization of gills in juveniles of the Argentinian Silverside, Odontesthes bonariensis (Valenciennes, 1835) (Teleostei: Atheriniformes). Anat Histol Embryol 35(2):76-83

World Health Organization, WHO (1994) Glyphosate. Environmental Health Criteria 159. WHO, Geneva

Zhu Y, Zhang F, Tong C, Liu W (1999) Determination of glyphosate by ion chromatography. J Chromatogr A 850:297-301

Publisher's Note Springer Nature remains neutral with regard to jurisdictional claims in published maps and institutional affiliations. 